\title{
Historia de la Radiología
}

\section{History of Radiology}

\author{
M. C. Binda ${ }^{1}$ \\ ${ }^{1}$ Editora Asociada de la Revista Argentina de Radiología, Buenos \\ Aires, Argentina
}

Rev Argent Radiol 2018;82:53-54.

\section{Adrian M. K. Thomas, Arpan K. Banerjee Historia de la Radiologia. Ediciones Journal, Buenos Aires, Argentina, 2017. (ISBN 978-9873954-6-0)}

Traducido por Federico Campana de: The History of Radiology, A.M.K. Thomas and A.K. Banerjee, Oxford Universisty Press, Oxford, UK, 2013.

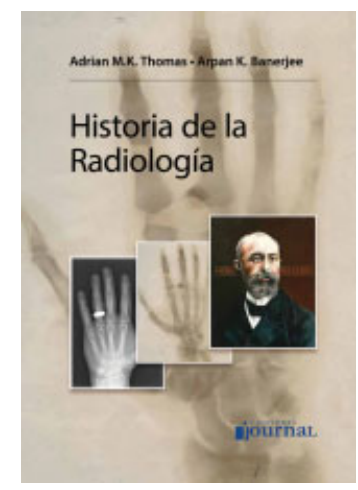

Este libro forma parte de una serie de publicaciones acerca de la historia de la medicina realizado por Oxford. Sus autores Adrian M. K. Thomas, y Arpan K. Banerjee, poseen una experiencia internacionalmente reconocida y antecedentes importantes en la investigación de la historia de la radiología y diagnóstico por imágenes.
Address for correspondence María del Carmen Binda, Revista Argentina de Radiologia, Arenales 1985, PB, C1124AAC CABA, Buenos Aires, Argentina (e-mail: rar@sar.org.ar).

En este volumen los autores hacen una descripción exhaustiva de la radiología desde sus orígenes, partiendo desde el descubrimiento de los rayos $\mathrm{X}$ y realizando un recorrido por los avances de los últimos 120 años de la especialidad del diagnóstico por imágenes. Sus 219 páginas se desarrollan en trece capítulos y tres apéndices, a saber: Wilhelm Röntgen y el descubrimiento, inicios de la radiología, radiología militar, radiología y cultura popular, radiología clásica, tomografía computada, resonancia magnética, ecografía, imágenes digitales y sistemas de archivo y comunicación de imágenes, radiología intervencionista, historia de la mamografía, medicina nuclear y radioactividad: desde la biología nuclear hasta las imágenes moleculares, revisión y futuro. A eso se suman 3 apéndices referidos a las primeras revistas británicas de radiología y a las primeras sociedades británicas de la especialización, con el añadido de una bibliografía comentada y una lista de lecturas.

La importancia del contenido de este volumen radica en la transcendencia que han tenido las imágenes en el diagnóstico médico en los últimos 120 años, y su imparable avance y sofisticación, con la enorme responsabilidad y necesidad de actualización permanente a los que ejercemos esta especialidad.

Considero que su lectura resultará de gran interés para los médicos y técnicos radiólogos, siendo invalorable la información sobre el origen y la evolución de la radiología que aporta a la historia de la medicina.
DOI https://doi.org/ 10.1055/s-0038-1639574. ISSN 1852-9992.
Copyright @ 2019 , Sociedad Argentina de Radiología. Publicado por Thieme Revinter Publicações Ltda., Rio de Janeiro, Brazil. Todos los derechos reservados.
License terms

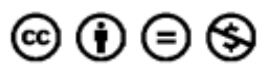

